\title{
PERANAN DINAS TENAGA KERJA DAN PERINDUSTRIAN DALAM MENINGKATKAN KESEMPATAN KERJA BAGI PENYANDANG DISABILITAS
}

\author{
Husna Fitria Arzul \\ Jurusan Administrasi Publik, FIS Universitas Negeri Padang \\ e-mail: husnafitria43@gmail.com \\ Afriva Khaidir \\ Jurusan Administrasi Publik, FIS Universitas Negeri Padang \\ e-mail: af.khaidir@gmail.com

\section{Adil Mubarak} \\ Jurusan Administrasi Publik, FIS Universitas Negeri Padang \\ e-mail: adilmubarak@yahoo.co.id
}

\begin{abstract}
The purpose of this study was explain the role of the Padang City Manpower and Industry Office in increasing employment opportunities for persons with disabilities. This research was qualitative research using descriptive methods. The data in this study were obtained through observations, interviews, and documentation studies. The validity test of the data in this study is by the method of triangulation. Based on the results of research and discussion was done found that the role of the Padang City Manpower and Industry Office in increasing employment opportunities for persons with disabilities in policy management was still limited to providing skills training. In an effort to improve employment opportunities for persons with disabilities there were still many obstacles faced by the agency.
\end{abstract}

Keywords: Role, job opportunity, persons with disabilities

How to Cite: Husna Fitria Arzul, Afriva Khaidir dan Adil Mubarak. 2019. Peranan Dinas Tenaga Kerja dan Perindustrian dalam Meningkatkan Kesempatan Kerja bagi Penyandang Disabilitas. 3(2): pp.135-143. DOI: https://doi.org/10.24036/jess/vol3-iss2

\section{Pendahuluan}

Kesempatan untuk bekerja bagi penyandang disabilitas masih sangat terbatas dan bahkan dipandang sebelah mata oleh pengusaha yang membutuhkan tenaga kerja. Mereka beranggapan bahwa penyandang disabilitas tidak mampu bekerja secara maksimal dengan keterbatasan yang dimiliki. Dengan anggapan seperti itulah maka sampai saat ini masih banyak perusahaan yang belum mempekerjakan penyandang disabilitas. Padahal Undang-undang Nomor 4 Tahun 1997 tentang Penyandang Cacat dalam pasal 14 menegaskan bahwa perusahaan negara dan swasta memberikan kesempatan dan perlakuan yang sama kepada penyandang cacat dengan mempekerjakan penyandang cacat di perusahaannya sesuai dengan 
jenis dan derajat kecacatan, pendidikan, dan kemampuannya, yang jumlahnya disesuaikan dengan jumlah karyawan dan/atau kualifikasi perusahaan.

Di Kota Padang sendiri, perusahaan yang mempekerjakan penyandang disabilitas masih sangat sedikit mengingat banyaknya penyandang disabilitas di Kota Padang. Untuk saat ini jumlah penyandang disabilitas usia dewasa di Kota Padang yang tersebar di 11 kecamatan mencapai 1.123 jiwa. Berdasarkan data dari Kantor Persatuan Penyandang Disabilitas Indonesia (PPDI) Kota Padang ratarata dari penyandang disabilitas tersebut tidak bekerja. Hal tersebut membuktikan bahwa kesempatan untuk bekerja bagi penyandang disabilitas masih sangat rendah.

Dalam merekrut karyawan baru, perusahaan masih memandang tenaga kerja disabilitas sebelah mata dengan melihat kondisi fisik tanpa mengetahui kemampuan yang dimiliki oleh penyandang disabilitas itu sendiri. Hal ini juga menimbulkan ketidakpercayaan diri dari penyandang disabilitas tersebut. Untuk menyetarakan hak-hak penyandang disabilitas dengan warga lainnya, Pemerintah Kota Padang telah mengeluarkan Perda No. 3 Tahun 2015 tentang Pemenuhan dan Perlindungan Hak-Hak Penyandang Disabilitas. Yang mana dalam pasal 27 dijelaskan bahwa setiap penyandang disabilitas memiliki kesempatan dan perlakuan yang sama untuk memperoleh pekerjaan dan harus memenuhi persyaratan jabatan, kualifikasi jabatan sesuai dengan jenis dan derajat kedisabilitasan.

Namun Perda tersebut masih belum tersosialisasikan dengan baik kepada perusahaan maupun masyarakat penyandang disabilitas itu sendiri. Sejak disahkannya perda tersebut masih ada beberapa perusahaan yang belum mempekerjakan penyandang disabilitas dikarenakan standar dari perusahaan itu sendiri yang mengutamakan penampilan bagi calon karyawannya. Bahkan beberapa perusahaan juga tidak mengetahui bahwa adanya aturan yang mengharuskan perusahaan untuk mempekerjakan penyandang disabilitas dengan jumlah yang disesuaikan dengan jumlah karyawannya.

Berdasarkan latar belakang tersebut terdapat beberapa permasalahan yaitu: (a) bagaimana peranan Dinas Tenaga Kerja dan Perindstrian Kota Padang dalam meningkatkan kesempatan kerja bagi penyandang disabilitas, (b) apa saja kendala yang ditemui dalam meningkatkan kesempatan kerja bagi penyandang disabilitas, dan (c) apa upaya yang dilakukan untuk meningkatkan kesempatan kerja bagi penyandang disabilitas.

\section{Tinjauan Kepustakaan}

\section{Konsep Peranan Lembaga Pemerintah}

Menurut Wursanto (2005) institusi atau lembaga adalah suatu kelompok yang menampung aspirasi masyarakat, baik yang mempunyai aturan secara tertulis maupun tidak tertulis, tumbuh dalam masyarakat serta bertujuan untuk mencapai tujuan bersama. Sedangkan institusi atau lembaga pemerintah adalah lembaga yang dibentuk oleh pemerintah berdasarkan suatu kebutuhan yang karena tugasnya berdasarkan pada suatu peraturan perundang-undangan melakukan kegiatan untuk meningkatkan pelayanan masyarakat dan meningkatkan taraf kehidupan kebahagiaan kesejahteraan masyarakat. 
Organisasi publik adalah organisasi yang didirikan untuk memenuhi kebutuhan masyarakat akan jasa publik dan layanan sipil. Organisasi publik adalah organisasi yang terbesar yang mewadahi seluruh lapisan masyarakat dengan ruang lingkup negara dan mempunyai kewenangan yang absah (terlegitimasi) di bidang politik, administrasi pemerintahan, dan hukum secara terlembaga sehingga mempunyai kewajiban melindungi warga negaranya, dan melayani keperluannya, sebaliknya berhak pula memungut pajak untuk pendanaan, serta menjatuhkan hukuman sebagai sanksi penegakan peraturan.

Dalam organisasi publik atau instansi pemerintah, pendekatan PAFHRIER karya Garson dan Overman dalam Febriana, dkk (2015) mendapatkan perhatian karena melihat peranan manajer sebagai pihak yang melayani masyarakat publik (adanya pengelolaan hubungan dengan pihak luar), dan bukan lagi sebagai pihak yang bekerja dalam kantor semata (tidak pernah mendatangi, memahami, dan mengartikulasikan kepentingan masyarakat). PAFHRIER merupakan singkatan dari Policy Analysis, Human Resource Management Financial Management, Information Management, and External Relations. Dalam penelitian ini penulis menggunakan doktrin PAFHRIER dalam melihat peranan Dinas Tenaga Kerja dan Perindustrian Kota Padang dalam meningkatkan kesempatan kerja bagi penyandang disabilitas berdasarkan fungsi-fungsi manajemen sebagai berikut:

a. Manajemen Kebijakan (Policy Analysis)

b. Manajemen Sumber Daya Manusia (Human Resource Management)

c. Manajemen Keuangan (Financial Management)

d. Manajemen Informasi (Information Management)

e. Manajemen Hubungan Luar (External Relations)

\section{Konsep Kesempatan Kerja}

Menurut Suroto (1992) kesempatan kerja merupakan daya serap dari penduduk yang masuk angkatan kerja yang telah bekerja, dinyatakan dalam bentuk jumlah tenaga kerja yang dipekerjakan (Employment). Kemudian menurut Simanjuntak dalam Siestri P. Kairupan (2013), dalam ilmu ekonomi kesempatan kerja berarti peluang atau keadaan yang menunjukkan tersedianya lapangan pekerjaan sehingga semua orang yang bersedia dan sanggup bekerja dalam proses produksi dapat memperoleh pekerjaan sesuai dengan keahlian, keterampilan dan bakatnya masing-masing.

\section{Konsep Penyandang Disabilitas}

Definisi penyandang cacat atau pengertian terhadap permasalahan penyandang cacat yang digunakan Undang-undang No. 4 Tahun 1997 tentang Penyandang Cacat, pasal 1 ayat 1 menyebutkan bahwa penyandang cacat adalah setiap orang yang mempunyai kelainan fisik dan/atau mental, yang dapat mengganggu atau merupakan rintangan dan hambatan baginya untuk melakukan secara selayaknya, yang terdiri dari: penyandang cacat fisik, penyandang cacat mental, serta penyandang cacat fisik dan mental.

Menurut Mulyono dalam Indah Triutari (2014) istilah penyandang disabilitas atau yang biasa disebut dengan anak berkebutuhan khusus atau anak dengan hambatan dapat dimaknai dengan "anak-anak yang tergolong cacat atau 
penyandang ketunaan dan juga anak potensial dan berbakat”. Kemudian menurut Sunardi dalam Mumpuniarti (1999) ada empat aspek dari penyandang cacat yang diungkapkan dalam proses identifikasi, yaitu aspek fisik, psikologi, sosial, dan vokasional.

Jenis-jenis kecacatan berdasarkan undang-undang penyandang cacat dapat dikelompokkan sebagai berikut:

a. Penyandang cacat fisik, terdiri dari:

1) Tuna Netra (Kelainan Indera Penglihatan)

2) Tuna Rungu Wicara (Kelainan pendengaran dan Bicara)

3) Tuna Daksa (Kelainan Tubuh)

b. Penyandang cacat mental, terdiri dari:

1) Tuna Laras

2) Tuna Grahita

c. Penyandang cacat fisik dan mental

\section{Metode Penelitian}

Penelitian ini menggunakan pendekatan kualitatif dengan metode deskriptif. Penelitian dilakukan di Dinas Tenaga Kerja dan Perindustrian Kota Padang. Informan dipilih menggunakan snowball sampling. Data primer diperoleh melalui wawancara dan observasi yang berkaitan dengan peranan Dinas Tenaga Kerja dan Perindustrian Kota Padang dalam meningkatkan kesempatan kerja bagi penyandang disabilitas. Sedangkan data sekunder diperoleh melalui dokumendokumen seperti profil Dinas Tenaga Kerja dan Perindustrian Kota Padang, profil bidang yang terkait, peraturan dan perundang-undangan, informasi media massa, dan berbagai data yang berkaitan dengan kesempatan kerja bagi penyandang disabilitas, serta dokumen data penyandang disabilitas. Keabsahan data diuji melalui teknik triangulasi metode. Triangulasi metode yang dilaksanakan pada penelitian ini yaitu dengan memandingkan data hasil pengamatan dengan data hasil wawancara dan membandingkan hasil wawancara dengan isi suatu dokumen yang berkaitan.

\section{Temuan dan Analisis Data Penelitian}

\section{Peranan Disnakerin Kota Padang dalam Meningkatkan Kesempatan Kerja Bagi Penyandang Disabilitas}

Peranan Disnakerin Kota Padang sebagai lembaga pemerintahan dalam meningkatkan kesempatan kerja bagi penyandang disabilitas sesuai dengan fungsi-fungsi manajemen yang dikemukakan oleh Garson dan Overman dengan menggunakan pendekatan PAFHRIER (Policy Analysis, Human Resource Management, Financial Managemet, Information Management, External Relations). Dalam organisasi publik atau instansi pemerintah, pendekatan PAFHRIER mendapatkan perhatian karena melihat peranan manajer sebagai pihak yang melayani masyarakat publik dan merupakan tanggung jawab para manajer publik (pemangku eselon) dituntut untuk menerapkannya secara tepat. 
a. Manajemen Kebijakan

Tugas pertama dari manajer publik adalah melakukan analisis kebijakan publik. Perlu diperhatikan bahwa hanya manajer publik pada level yang lebih tinggi atau yang diberi wewenang dan tanggung jawab yang melakukan tugas tersebut. Kebijakan mengenai kesempatan kerja bagi penyandang disabilitas sudah tertuang dalam UU No. 4 Tahun 1997 tentang Penyandang Cacat dan UU No. 19 Tahun 2011 tentang Pengesahan Convention On The Rights Of Persons With Disabilities (Konvensi Mengenai Hak-Hak Penyandang Disabilitas). Dalam pelaksanaan kebijakan di daerah mengenai kesempatan kerja bagi penyandang disabilitas, Kota Padang sendiri telah mengeluarkan Perda No. 3 Tahun 2015 tentang Pemenuhan dan Perlindungan Hak-Hak Penyandang Disabilitas.

Berdasarkan hasil penelitian yang didapatkan kebijakan dalam pemenuhan hak-hak penyandang disabilitas dalam meningkatkan kesempatan kerja bagi penyandang disabilitas adalah merekomendasikan penyandang disabilitas ke perusahaan dan memberikan pelatihan keterampilan bagi penyandang disabilitas itu sendiri. Kebijakan mengenai kesempatan kerja bagi penyandang disabilitas dilaksanakan oleh OPD (Organisasi Perangkat Daerah) terkait diantaranya Dinas Tenaga Kerja dan Perindustrian serta Dinas Sosial Kota Padang. Menurut Lasswell dan Kaplan dalam M. Solly (2007), kebijakan itu sebagai sarana untuk mencapai tujuan. Kebijakan tertuang dalam program yang diarahkan kepada pencapaian tujuan, nilai-nilai, dan praktek. Bentuk implementasi kebijakan yang telah ditetapkan oleh Disnakerin Kota Padang adalah berupa pembuatan programprogram kerja dan pelaksanaan kegiatan-kegiatan yang dapat meningkatkan kesempatan kerja bagi penyandang disabilitas.

b. Manajemen Sumber Daya Manusia

Manajemen sumber daya manusia adalah fungsi manajemen yang berhubungan dengan rekrutmen, penempatan, pelatihan, dan pengembangan organisasi. Dalam manajemen SDM perlu diperhatikan jumlah, jenis kualitas, dan distribusi dan utilitasi SDM yang bekerja dalam organisasi. Jumlah, jenis dan kualitas sangat berkenaan dengan tuntutan pekerjaan-pekerjaan yang ada. Dari keseluruhan sumber daya yang tersedia dalam suatu organisasi, baik organisasi publik maupun swasta SDM-lah yang paling penting dan menentukan. Menurut Moses N. Kiggunndu dalam Ambar T. Sulistiyani dan Rosidah (2009) manajemen SDM adalah pengembangan dan pemanfaatan pegawai dalam rangka tercapainya tujuan dan sasaran individu, organisasi, masyarakat, bangsa dan internasional yang efektif.

Kinerja dari pengawas ketenagakerjaan dapat mengurangi terjadinya pelanggaran-pelanggaran aturan ketenagakerjaan. Dalam melaksanakan tugasnya, pengawas ketenagakerjaan akan memeriksa perusahaan-perusahaan yang tidak mematuhi peraturan yang telah dibuat. Karena jumlah pengawas ketenagakerjaan wilayah Sumatera Barat hanya berjumlah 38 orang, maka pemeriksaan yang dilakukan belum maksimal. Jika didapati perusahaan yang melanggar maka akan diberi teguran berupa surat peringatan, jika masih saja melanggar maka langkah selanjutnya yang dilakukan adalah membawa kasus tersebut ke pengadilan. Sejauh ini di Kota Padang belum ada perkara yang sampai ke tahap pengadilan, hanya sebatas peringatan. 
Selain pengawas ketenagakerjaan, penyandang disabilitas itu sendiri juga harus meningkatkan kemampuan diri sendiri sehingga akan membuka jalan bagi mereka untuk mendapatkan pekerjaan. Hingga saat ini masih banyak penyandang disabilitas yang belum memiliki pekerjaan tetap. Salah satu faktor penyebabnya adalah rendahnya pendidikan yang dimiliki oleh penyandang disabilitas itu sendiri. Untuk mengimbangi tingkat pendidikan yang masih rendah, beberapa upaya telah dilakukan seperti memberikan pelatihan keterampilan. Namun pelatihan yang diberikan masih belum maksimal dikarenakan hanya dilakukan dalam satu tahun sekali.

c. Manajemen Keuangan

Lilik Saripah (1988) mengemukakan bahwa manajemen keuangan sebagai keseluruhan aktivitas yang bersangkutan dengan usaha untuk mendapatkan dana dan menggunakan atau mengalokasikan dana tersebut. Pengelolaan keuangan merupakan tanggung jawab seorang manajer meskipun dalam kenyataan ditangani oleh unit keuangan. Tugas utama seorang manajer dalam bidang ini adalah bagaimana mencari dana, merencanakan dan mengalokasikannya sesuai dengan kebutuhan yang ada, memanfaatkannya secara optimal, dan mengendalikan penggunaannya sesuai rencana. Sumber dana yang didapatkan oleh Disnakerin Kota Padang dalam melakukan kegiatan guna meningkatkan kesempatan kerja bagi penyandang disabilitas berasal dari APBD (Anggaran Pendapatan Belanja Daerah) Kota Padang.

Sebelum mengusulkan dana kepada Tim APBD Kota Padang, Disnakerin terlebih dahulu mengadakan rapat untuk merancang anggaran yang akan dibutuhkan untuk pelaksanaan program kerja maupun kegiatan-kegiatan lainnya. Setelah anggaran tersebut disetujui oleh Tim APBD barulah kemudian dicairkan untuk pelaksanaan program kerja. Dalam pelaksanaan program kerja maupun kegiatan yang berkaitan dengan kesempatan kerja bagi penyandang disabilitas, tentu ada biaya-biaya tak terduga diluar rancangan anggaran yang dapat mengakibatkan kekurangan biaya selama pelaksanaan kegiatan. Mengingat hal tersebut, Disnakerin selalu membuat rancangan anggaran setiap tahunnya sebelum mengusulkan dana ke Tim APBD Kota Padang. Tujuannya adalah untuk meminimalkan biaya yang dibutuhkan dalam melaksanakan sebuah kegiatan.

d. Manajemen Informasi

Manajemen informasi sangat penting dalam suatu organisasi lebih-lebih organisasi yang telah berkembang dan kompleks. Informasi-informasi yang digunakan dalam perencanaan, pengambilan keputusan, penilaian pekerjaan, sistem monitoring dan pengendalian, harus ditata, disusun dan disimpan secara teratur, sehingga dapat dengan mudah diperoleh apabila dibutuhkan. Pengelolaan informasi tersebut kini sangat menentukan keberhasilan suatu organisasi, dan karenanya dikelola dalam suatu bidang disiplin yang disebut MIS (Management Information System). Menurut Davis dalam Abdul Kadir (2003) penyebarluasan informasi adalah memberikan data yang telah dikelola menjadi informasi kepada masyarakat yang membutuhkan informasi. Dalam penyebarluasan informasi yang sangat penting untuk diperhatikan adalah ketepatan informasi, sarana tujuan dan keakuratan dari informasi tersebut.

Dalam menyebarluaskan informasi mengenai lowongan pekerjaan bagi penyandang disabilitas maupun informasi-informasi lainnya, Disnakerin 
memanfaatkan media sosial dan media cetak. Salah satu media yang digunakan berupa website dinas itu sendiri yaitu www.disnakerin.padang.go.id yang dapat diakses oleh penyandang disabilitas dan masyarakat umum. Selain menggunakan website, informasi mengenai lowongan pekerjaan juga disebarluaskan melalui media cetak berupa koran harian. Demi memudahkan dinas dalam meningkatkan kesempatan kerja bagi penyandang disabilitas, peran aktif dari perusahaan yang membutuhkan tenaga kerja juga harus ditingkatkan lagi. Sejauh ini ada beberapa perusahaan yang menyampaikan langsung kepada dinas bahwa mereka membutuhkan tenaga kerja disabilitas yang dilengkapi dengan persyaratanpersyaratan yang dibutuhkan.

e. Manajemen Hubungan Luar

Suatu organisasi publik berada dalam suatu lingkungan yang sangat mempengaruhi dinamikanya. Karena itu, suatu organisasi harus menjaga hubungan luar dengan lingkungan dalam maupun diluar organisasi itu sendiri. Salah satu cara menjaga hubungan baik dengan lingkungan luar organisasi adalah dengan melakukan koordinasi maupun kerjasama. Menurut Yuskal dan Rifma (2002) kerjasama berarti bekerja bersama-sama kearah tujuan yang sama. Sejauh ini belum ada kerjasama yang terjalin antara Disnakerin dengan perusahaan yang ada di Kota Padang. Hal ini tentu sangat menyulitkan bagi penyandang disabilitas karena dengan keterbatasan fisik yang mereka miliki tentu menjadi pertimbangan yang sulit bagi perusahaan untuk menerimanya sebagai karyawan jika tidak didukung dengan kerjasama antara dinas dengan perusahaan.

Selain kerjasama dengan instansi terkait, dukungan luar juga sangat dibutuhkan dalam upaya meningkatkan kesempatan kerja bagi penyandang disabilitas terutama dari masyarakat disabilitas maupun masyarakat umum. Peran serta masyarakat dalam meningkatkan kesempatan kerja bagi penyandang disabilitas bisa dilakukan dengan cara meningkatkan kemampuan diri serta kepercayaan diri dari masing-masing penyandang disabilitas sehingga akan memudahkan mereka dalam mendapatkan pekerjaan.

\section{Kendala yang Ditemui Dalam Meningkatkan Kesempatan Kerja bagi Penyandang Disabilitas}

Dalam melaksanakan sebuah kegiatan tentu tidak luput dari kendala-kendala maupun hambatan yang bisa mengakibatkan kegiatan tersebut tidak berjalan dengan baik. Adapun kendala menurut Hansen dan Mowen dalam Setyaningrum dan Hamidi (2008) dikelompokkan berdasarkan asalnya yaitu kendala internal dan kendala eksternal. Begitu juga dalam meningkatkan kesempatan kerja bagi penyandang disabilitas, Disnakerin Kota Padang menemui beberapa kendala baik yang berasal dari dalam maupun dari luar lingkungan dinas. Adapun kendalakendala yang ditemui dalam meningkatkan kesempatan kerja bagi penyandang disabilitas adalah:

a. Jumlah pengawas ketenagakerjaan yang belum mencukupi

b. Kesulitan mencarikan instruktur khusus bagi penyandang tuna rungu wicara

c. Tingkat pendidikan penyandang disabilitas di Kota Padang masih rendah

d. Kurangnya kesadaran perusahaan terhadap aturan ketenagakerjaan 


\section{Penutup}

\section{Kesimpulan}

Berdasarkan hasil temuan dan pembahasan penelitian yang telah dilakukan, dapat ditarik kesimpulan, antara lain:

a. Peranan Disnakerin Kota Padang dalam meningkatkan kesempatan kerja bagi penyandang disabilitas pada manajemen kebijakan adalah merekomendasikan penyandang disabilitas ke perusahaan dan memberikan pelatihan keterampilan kepada penyandang disabilitas, pada manajemen SDM adalah dengan pembagian kerja yang merata kepada seluruh pengawas ketenagakerjaan, pada manajemen keuangan terlihat pada penganggaran biaya untuk pelaksanaan kegiatan, pada manajemen informasi dalam bentuk penyebarluasan informasi melalui media cetak, media online, dan mading kantor, dan pada manajemen hubungan luar belum terlaksana dengan baik karena belum ada kerjasama yang terjalin antara Disnakerin dengan perusahaan-perusahaan yang ada di Kota Padang.

b. Kendala yang ditemui dalam meningkatkan kesempatan kerja bagi penyandang disabilitas adalah kurangnya jumlah pengawas ketenagakerjaan, kesulitan mencarikan instruktur khusus tuna rungu, tingkat pendidikan penyandang disabilitas yang masih rendah, dan kurangnya kesadaran perusahaan terhadap aturan ketenagakerjaan.

\section{Saran}

Berdasarkan hasil pengamatan dan penelitian yang telahdilakukan saran yang dapat diajukan untuk meningkatkan kesempatan kerja bagi penyandang disabilitas adalah memberikan pelatihan keterampilan secara maksimal. Pelatihan yang selama ini hanya dilakukan sekali dalam satu tahun agar ditingkatkan lagi paling tidak sekali dalam satu bulana sehingga penyandang disabilitas lebih percaya diri dalam melamar pekerjaan ke perusahaan-perusahaan.

\section{DAFTAR KEPUSTAKAAN}

Abdul Kadir. 2003. Pengenalan Sistem Informasi. Yogyakarta: Sinar Baru

Ambar T. Sulistiyani dan Rosidah. 2009. Manajemen Sumber Daya Manusia Konsep, Teori dan Pengembangan dalam Konteks Organisasi Publik. Yogyakarta: Graha Ilmu

Febriana Chadijah, Mochammad Mustam dan Hesti Lestari. 2015. Manajemen Pengembangan Objek Wisata Kawasan Kota Lama Semarang. Journal of Public and Management Review Vol. 4 No. 4 Tahun 2015

Ig Wursanto. 2005. Dasar-Dasar Ilmu Organisasi. Yogyakarta: Andi

Indah Triutari. 2014. Persepsi Mahasiswa Penyandang Disabilitas Tentang Sistem Pendidikan Segregasi dan Pendidikan Inklusi. Jurnal Ilmiah Pendidikan Khusus Vol. Nomor, September 2014

Lilik Saripah. 1988. Pendidikan Konsumen. Jakarta: IKIP Jakarta 
M. Solly Lubis. 2007. Kebijakan Publik. Bandung: Mandar Mandur

Mumpuniarti. 1999. Pendidikan Penyandang Cacat dan Sumbangnya Dalam Pembangunan Nasional. Cakrawala Pendidikan. Th XVIII. No. 3

Rina M. Setyaningrum dan Muhammad Fauzan Hamidi. 2008. Analisis Biaya Produksi Dengan Pendekatan Theory Of Constraint Untuk Meningkatkan Laba (Studi Pada PG Krebat Baru Malang). Jurnal Riset Ekonomi Dan Bisnis Vol. 8. No. 1

Siestri Pristina Kairupan. 2013. Pengaruh Domestik Regional Bruto (PDRB), Inflasi dan Belanja Daerah Pengaruhnya Terhadap Kesempatan Kerja di Sulawesi Utara Tahun 2000-2012. Jurnal EMBA Vol. 1 No. 4

Suroto. 1992. Teori Ekonomi. Jakarta: PT. Raja Grafindo Persada

Yuskal Kusman dan Rifma. 2002. Kepemimpinan Pendidikan. Padang: UNP Administrasi Pendidikan

\section{Sumber Peraturan Perundang-Undangan}

Undang-undang Nomor 4 Tahun 1997 Tentang Penyandang Cacat

Peraturan Daerah Kota Padang Nomor 3 Tahun 2015 Tentang Pemenuhan dan Perlindungan Hak-Hak Penyandang Disabilitas 